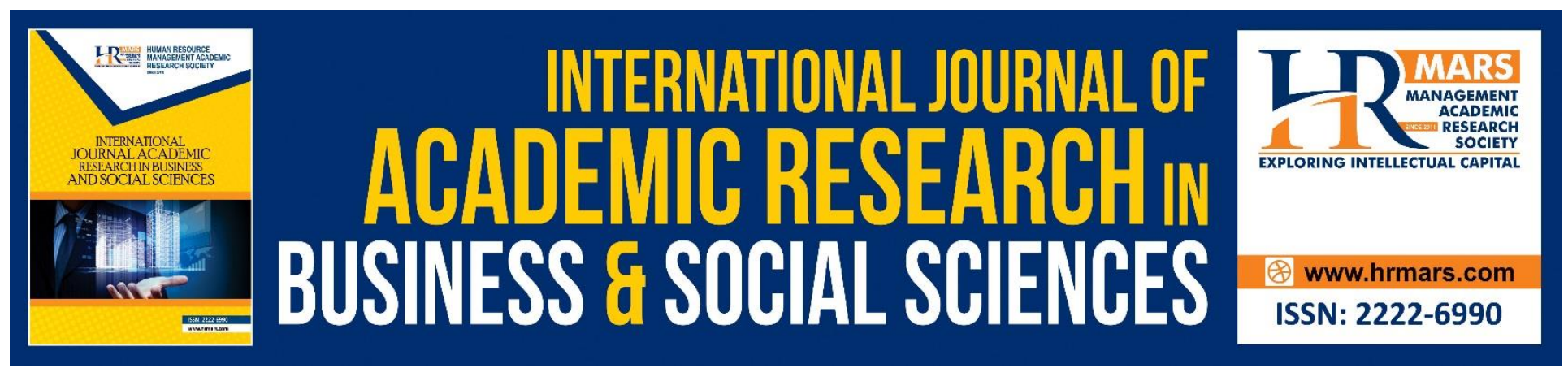

\title{
Principals' Behaviour and Teachers' Performance at Secondary Schools in Rural Area of Pakistan
}

Saima Maqbool, Shaik Abdul Malik Bin Mohamed Ismail, Saira Maqbool, Muhammad Zubair

To Link this Article: http://dx.doi.org/10.6007/IJARBSS/v9-i1/5481

DOI: $\quad 10.6007 /$ IJARBSS/v9-i1/5481

Received: 13 Dec 2018, Revised: 08 Jan 2019, Accepted: 13 Jan 2019

Published Online: 16 Feb 2019

In-Text Citation: (Maqbool, Ismail, Maqbool, \& Zubair, 2019)

To Cite this Article: Maqbool, S., Ismail, S. A. M. B. M., Maqbool, S., \& Zubair, M. (2019). Principals' Behaviour and Teachers' Performance at Secondary Schools in Rural Area of Pakistan. International Journal of Academic Research in Business and Social Sciences, 9(1), 788-801.

Copyright: (C) 2019 The Author(s)

Published by Human Resource Management Academic Research Society (www.hrmars.com)

This article is published under the Creative Commons Attribution (CC BY 4.0) license. Anyone may reproduce, distribute, translate and create derivative works of this article (for both commercial and non-commercial purposes), subject to full attribution to the original publication and authors. The full terms of this license may be seen

at: http://creativecommons.org/licences/by/4.0/legalcode

\section{Vol. 9, No. 1, 2019, Pg. 788 - 801}

Full Terms \& Conditions of access and use can be found at http://hrmars.com/index.php/pages/detail/publication-ethics 


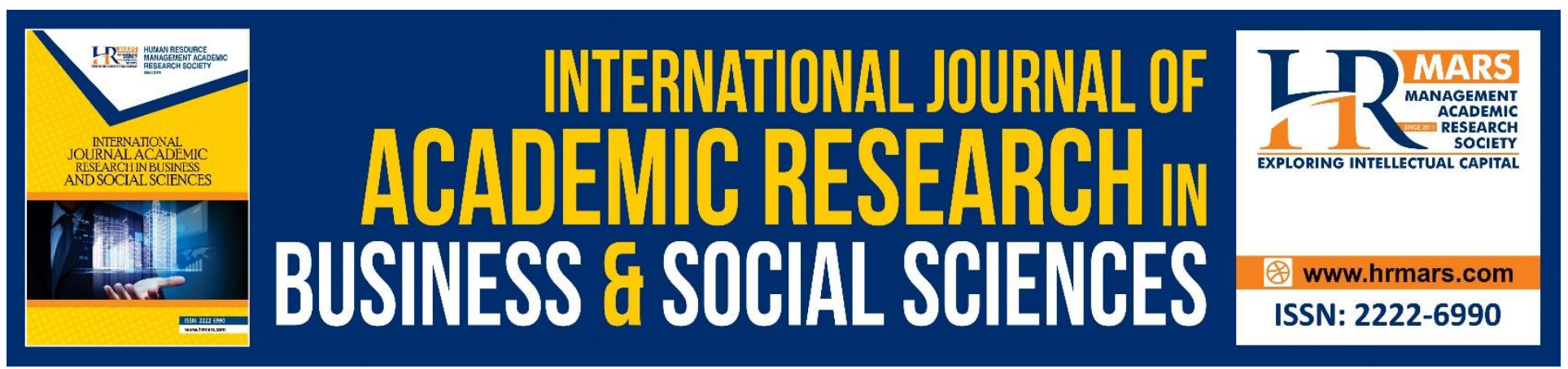

\title{
Principals' Behaviour and Teachers' Performance at Secondary Schools in Rural Area of Pakistan
}

\author{
Saima Maqbool \\ PhD Scholar, Department of Educational Studies, University of Science Malaysia. \\ Email: saima@student.usm.my \\ Dr. Shaik Abdul Malik Bin Mohamed Ismail \\ Associate Professor, Department of Educational Studies, University of Science Malaysia. \\ Dr. Saira Maqbool \\ Assistant Professor, Department of English Language and Linguistics Alama Iqbal Open University \\ Islamabad, 4400, Pakistan. \\ Muhammad Zubair \\ Khusal Khan Khattak University Karak, Pakistan
}

\begin{abstract}
The aim of the current study was to investigate the principals' behaviour effects on the teachers' classroom performance. The main hypothesis of the research were, $H_{0} 1$ : There is no significant relationship between the principals' Overall leadership behavior and teachers' performance in the classroom, $\mathrm{H}_{\mathrm{o}} 2$ : There is no worth mentioning connection between the principals' leadership task oriented behavior and teachers' performance in the classroom and $\mathrm{H}_{0} 3$ : There is no significant relationship between the principals' leadership relationship-oriented behavior and teachers' performance in the classroom. It was a descriptive survey research. The sample was conveniently selected form the population of district karak (a ruler area of Pakistan). Total 67 principals, 335 SST and SSs teachers and 2526 students were selected for the data collection. Questionnaires adopted form Teacher Classroom Performance Questionnaire (TCPQ) and the Management Behaviour Dimensions Questionnaire (MBDQ) were used. The data was tabulated and analyzed in SPSS through Person correlation. Some practical recommendations were given in accordance with research and literature review.
\end{abstract}

Keywords: Rural Area Education, Teachers' Performance, Pakistan 


\section{Introduction}

Teachers play central role in ensuring schools performance which increases or decreases every year depending on different factors (Cole, 2008). Teachers need to be motivated and supported by the principal to enable them to play this role effectively. The principal's part can be crucial in this regard. If teachers have good relationship with the principal of their school and are given handsome salaries and are given due share in the decision making process of school, it will bring considerable improvement in teachers' performance. Performance is an important factor which determines the worth of people in the work place. Performance engenders sense of responsibility and leads to the achievement of comprehensive career objectives and enhances output of an organization (Suebwongpat, 2014).

Evans (1998) has highlighted various factors like low salaries and status, growing class size and drastic changes in educational system undermines the morale and satisfaction level of teachers like. Ridzuan et al., (2018) also says that "the more the work relationship the higher the level of employee self-satisfaction". In recent years it has been found that laziness, irregularity and absenteeism negatively effects performance of teachers (Alimba, 2013). De Witte and Marques (2010) state that excellence within any organization is directly dependent on its output which is strongly proportional to employee' performance. Employees deliver when they are satisfied and an organization will achieve excellence due to the good performance of its employees. Consequently, output and productivity will increase. The success or failure of school is directly dependent on the leadership of principal, his competence and his managerial skills. These management skills can be shown in office management, curriculum management, staff development, motivation and in keeping good relationship with the community with the ultimate objective of improving the performance of students (Humphreys \& Einstein, 2004). Glanz (2005) notes that excellence of a schools depends on the positive influence of its leadership behaviour. If the principal is incompetent the results will be in negative. Hallinger, (1992) in his research examines interdependence of principal leadership behaviour and teachers' performance. Many researches have been conducted about the principals' leadership style and teachers' stress, job satisfaction and efficacy, turnout etc in many countries (Calik, et al. 2012; Walker \& Slear, 2011; Yilmaz 2007: Riffat-un-NisaAwan \& Bigger, 2008 Hoe ,2003; Simanjuntak, Pandjaitan, \& Kuswanto, 2018) But the present study strives to investigate the principals behaviour and the teachers' classroom performance at secondary level in Pakistan.

\section{Background of the Study}

For a nation to be successful and opulent, human capital is considered to be very essential and inevitable resource. The maximum utilization of all other assets and reserves of the nation like financial and natural reserves etc heavily rely on the talents and capabilities of human capital. Human resource plays a considerable part in the dynamics of a business environment. Organization is a place where people get together to achieve certain goals in a particular fashion (Child, 1972). Such organizations are major sources of social interaction and help in developing relations among the employees. Organizations are goal oriented where individuals work in a coordinated manner with defined frontiers (Miner, Bassof, \& Moorman, 2001). These individuals intend to fulfill their requirements which demands more power and coordination, which means that the goals can be achieved only if we work in a collaborative working environment. 
The development of an organization is based on the internal and external factors. Internal factors include communication system, organizational structure, and employee's moral and cultural changes while external factors comprise of technological changes, economic conditions, environmental change and competitors. These factors may have a productive or destructive effect on the overall progress of the developing organization. All these mentioned factors have a strong influence on the performance and level of satisfaction of the workforces. For an organization to be effective it must focus on job-satisfaction which leads to more productive results (Bhatti, \& Qureshi, 2007; Hunter \& Tietyen, 1997).

A standout amongst the most profoundly explored component in the present competitive situation is performance since it is concerned with different mental and working environment issues. Performance is the physical and mental prosperity of workers which have insinuate association with the efficiency, absenteeism, workers' relations and turnover (Kunze, Boehm \& Bruch,, 2011). Performance has a close relationship with human motivational speculations. The most well-known hypotheses require hierarchy theory by Maslow, two factor theory by Herzberg and Job Characteristics Model. Maslow's need hierarchy proposes the five levels of human prerequisites comprising of fundamental needs, security, social need, adoration and self-realization.

Likewise, two factor theory proposed Hygiene and Motivation factors to determine the satisfied and disappointed workers. Hygiene factors are related with employment dissatisfaction including working condition, organizational policies, principles and association with peers and so on. When hygiene factors are conveyed to workers they can accomplish an impartial state (neither fulfilled nor disappointed). So as to fulfill the workers, organizations need to concentrate on providing inspiration factors, for example, recognition, obligation and accomplishment. The two fundamental elements of performance are intrinsic as well as extrinsic. The nature of intrinsic factors is psychological that originates from inside the person as illuminated in Job Characteristics Model, the five key employment attributes: identity of tasks, diversity in skills and importance of workload, feedback and autonomy, influence psychological states which contributes to performance. While extrinsic factors of fulfillment originate from the external setting in which the individual works. In order to make workers more beneficial, productive and fulfilled both intrinsic as well as sources must be given (Kasser, Davey \& Ryan 1992; Burton, 2012; Lee \& Wilkins, 2011) .

Numerous theories and definitions make clear that institution may not accomplish worker's fulfillment just by giving handsome compensation. For an institution to make progress toward worker's fulfillment, the HR experts must deal with different factors as well which comprised of trust, equal treatment with all workforce, a workplace that is free from pressure, morale issues, they should be provided professional advancement opportunities, a sense of security and excellent communication system respect to performance and organizational health and so forth (Sparks, Faragher \& Cooper). Similarly, employees want to be a part of fair and ethical organizations. When they get the feeling of an unbiased treatment by the organization in every respect, they become willing to demonstrate more positive and responsible attitude. Organizational justice is concerned with all matters of workplace behavior including the relationship of managers and subordinates, their remunerations, access to training and gender equality. The base of Organizational Justice is Equity Theory which was first developed in the early 1960 s by behavioural psychologist John S. Adams (Morrison \& Robinson, 1997). 
This theory is concerned with describing and assessing the employees' satisfaction who make judgments on the basis of the efforts they put in (inputs) and the rewards they get in return (output). The 'inputs,' or what the employee gives to an organization includes time, devotion, level of effort, tolerance, flexibility, zeal, personal sacrifice, skill, abilities and level of trust in management whereas outcomes or the returns that employees expect attractive salaries, job security and employee benefits. It also covers intangible aspects such as praise, sense of achievement, recognition and respect. In business psychology, organizational justice comes under the domain of equity theory which is concerned with employee's assumptions of an organization's internal and external behavior. These assumptions affect the employee's attitude (Tsui, Pearce, Porter \& Tripoli, 1997). As organizational justice is the fundamental aspect for the success of every organization it was first presented by Greenberg in 1987 which refers to employee's opinion about their organization's actions, attitude, role, in what manner it affects the employee's behavior and attitude at workplace. Distributive, procedural and interactional justices are the three core components of organizational justice. Like every organization educational institutes also have the same psychological setup as they also follow the same rules and regulation of HR.

For many decades principals have been using routine management teachers like planning, organizing, monitoring and evaluation. These works include issuing orders, dealing with school budget, arranging timetable, monitoring attendance and absence of teachers and students. These works have been very important however due to greater changes in education and the changing prospects for students; the role of principal has undergone a drastic change. Today the schools are faced with gigantic challenges despite abundance of knowledge and technological advancement (Leonard, 2010). Which means that new type of leadership style for the educational organizations is needed to cop up with such advancements and face new challenges.

In the old and conventional education system the primary focus was on school management to ensure smooth functioning, substitute arrangement and staff and students discipline (Bandara,, Chand, Chircu, Hintringer, Karagiannis, Recker, \& Welke, 2010). It is now being argued that old principals did not have management skills. A good and effective principal not only concentrates on educating his students and helping and motivating teachers. He is also careful about performing the routine works, which are inevitable for achieving the targeted goals all these roles contribute towards continuous progress of school (Bryk, Gomez, Grunow, \& LeMahieu, 2015).

The principal should keep in mind that they are not the sole leaders. They are to interact with different groups of leaders. They are to work side by side to achieve the objective of improving the quality of student learning. In other words, if the teachers and principals are working in close coordination with the spirit of one team, the students' involvement and participation will increase resulting in positive learning out comes (Hanaysha 2016). There has been much debate on the relationship between leadership behaviour and teacher's performance, but the fact remains that teacher's performance is almost inconceivable without positive leadership behavior. Almost all the researchers are of the opinion that there exists close affinity between teacher's achievement and leadership behaviour. Educational leadership is considered to be an integral part of conducive learning environment (Dumas, 2010). A competent principal can initiate steps for school improvement, create favorable environment for learning and friendly working environment for subordinate's staff like teachers and other school officials (Hanaysha, 2016). 
The foremost responsibilities of a principal to ensure result orienting teaching and learning with the desired goal of improving teacher's performance. Education today is in need of such leaders who can deliver in unfavorable complex environment. Teacher's achievement is directly dependent on conducive psychological environment. He emphasizes that leader can create such environment by framing strategies with special focus on targeted goals and giving teachers options in instructional methods and amply rewarding them for their performance. Such environment can be created by ensuring team work, carefully managing teaching time with occasional self-paced instruction (Pfeffer, 2005).

A leader plays central role in any organization. The success of an institution depends on how its leader uses his authority. School leader has to keep balance among varying interests. Leaders need to have good relationship with teachers to ensure their good performance relationship between leader and teacher is inevitable for getting the desired objectives (Barth, 2001).

The work of the school is incessant. The leader has to keep balance between different leadership behaviors and relationships among members of the organization with the desired objective of improving teacher achievement. Education is just like a whole with different closely interconnected parts based on one foundation of knowledge. Education is just like a living entity. Leader is just like a backbone. Leadership is compulsory but not enough. It gives support and at the same time requires support (de Koster, Stam, \& Balk, 2011).

It gives direction and provides stability and safety but can be harmed. The entire system has to suffer if the leadership is efficient in capabilities, maintaining balance between the demand of personal and professional life is an ongoing struggle. Leadership strives at the same time. Leaders are role models for their subordinate's officials. Institutions are dependent on leadership for their future success who deliver through the process of self-renewal and correction (Chodkowski, 1991).

Though in theory school leadership appears simple but in practical it is very much complicated and challenging. Leadership is defined as the ability to do things with the help and co-operation of other people within an organization. Leadership involves interaction among members of an organization and involves structuring and restructuring of the situation keeping in view the expectations and perceptions of its members (Bass, B. M., \& Bass, 2009).

In leadership one group member motivates and utilizes the potentialities of others group. Leadership concentrates on how to fulfill the expectations of its subordinate (Bass \& Riggio, 2006). Leadership is a pattern of behaviour used by leader to influence group members and make decision regarding objectives, strategies and functioning of the group activities. Leadership is an approach in which the leader directs, executes plans and motivates people in order to achieve the organizational goals. In short effectiveness of interaction between leader and group member is the parameter for measuring the success of an organization (Jung, Chow \& Wu, 2003). A principal is a kind of a leader which stands as a luminar for the teachers and the students. The principal tries to manage a staff which can focus on the critical tasks and also remain as comfortable individuals. He always tries to adjust competent staff under his leadership for the well-being of the institution. He maintains suitable environment for the facilitation of academic performance. As a whole, he strives his best to polish the defunct aspects or elements of the institution (Leonard, 2010).

Education is our basic human right which not only gives knowledge but also enlightens one ethically, socially and religiously. It is considered to be the sole way to realize ones dreams and 
aspirations. Education is the means which opens the window of opportunities for human being to get what they aspire for. Education is not just learning about books but also involves learning about life (Hansen, 2017).

Education makes one discriminate between rights and wrong. It engenders positive mentality and relives one of worries. It enables us to realize our dreams (Coker, 2012). It is powerful weapon in the hands of human being enabling them to live prosperous lives. Education enables one to have an insight into the realities of life to think independently to question and be a shrewd administrator (Bass, 1999). It enhances one's skills and creates awareness about one's rights obligations. It explores new world of opportunities. Educations play an instrumental role in the grooming of an individual. It gives social training. Keeping in view the importance of education many countries are striving hard to equip their nations with modern and standard education (Fenwick \& Edwards, 2010).

\section{Objectives of the Study}

1. To identify principals' leadership behaviour as assessed by secondary school teachers.

2. To find out the teachers' performance in the classroom as assessed by $10^{\text {th }}$ grade students at secondary and higher secondary school level

3. To trace out relationship between principal's leadership behavior and teachers' performance in the classrooms at secondary and higher secondary school level

\section{Hypotheses of the Study}

$\mathbf{H}_{\mathbf{0}} \mathbf{1}$ : There is no significant relationship between the principals' Overall leadership behavior and teachers' performance in the classroom.

$\mathbf{H}_{\mathbf{0}}$ 2: There is no worth mentioning connection between the principals' leadership task oriented behavior and teachers' performance in the classroom.

$\mathbf{H}_{\mathbf{0}}$ 3: There is no significant relationship between the principals' leadership relationship-oriented behavior and teachers' performance in the classroom.

\section{Research Design}

It was a descriptive as well as correlative research study in nature. The relationship between principal's leadership behaviour and teachers' classroom performance were determined, the leadership behaviour of school principals was found through the adopted question naire administered to the Govt: High and Higher Secondary School teachers.

Whereas classroom performances of the teachers were assessed through the adopted questionnaire administered to the $10^{\text {th }}$ Grade students. The data was analyzed through descriptive Statistics that is percentage, means, standard deviation and single regression analysis. The relationship between principal's leadership behaviour and teachers' classroom performance was determined through Pearson Product Moment method $(r)$ correlation and Principal's demographic qualification that is ages, teaching experience, academic qualification and professional qualification through simple percentage. 


\section{Population and Sampling of the Study}

In this study, all the principals, teachers and students working and studying at secondary and higher secondary level in Karak District of Pakistan constituted the population of the study. According to the Annual Statistical Report of Government Schools published by Elementary and Secondary Education Khyber Pakhtunkhwa, there were total 67 Govt: High \&higher secondary schools in Karak District. In these schools, the total number of principals, teachers and students were 67, 570 and 3150 respectively (EMIS, 2016). For the sake of validation of the findings, sixty-seven (67) Principals/Heads of the Institutions of the District Karak which is $100 \%$ population was taken as sample of the study. For the assessment of the leadership behaviour of the school principals, (05) five SSTs and SSs teachers from each school teaching to secondary classes were selected through convenient sampling technique. In this way, total 335 teachers were selected.

For the assessment of the same teachers' performance of each school, 36 students were selected from each secondary school while in case of higher secondary school, 45 students were selected from each school. In this way, a sample of total 2526 students were selected through convenient sample technique.

\section{Research Instruments}

Questionnaires were used for the collection of data to find out the principals' leadership behavior. For this purpose, the Management Behaviour Dimensions Questionnaire (MBDQ) developed by Skindar (2001) was administered to the teachers of the Govt: High \& Higher Secondary Schools (Annexure B). This questionnaire was designed on four-point likert scale i.e., Always, Sometimes, Often and Never and these were rated as 4, 3, 2, and 1.

In order to find out the teachers' performance in the classrooms, Teacher Classroom Performance Questionnaire (TCPQ) developed by Mehmoood (1997) was administered to the students of $10^{\text {th }} \& 12^{\text {th }}$ grade (Annexure $\mathrm{C}$ ). This questionnaire was also designed on four-point likert scale i.e., Always, Sometimes, Often and Never and these were rated as 4, 3, 2, and 1. Demographic Variable Information Performa (DVIP) was provided to the principals for general information (Annexure D).

\section{Data Collection}

In order to collect data, the Department of Education and Research, Khushal Khan Khattak University Karak requested the District Education Officer (M) Karak for granting formal permission to administer the questionnaire to the secondary school teachers and $10^{\text {th }} \& 12^{\text {th }}$ grade students of the sample schools. The District Education Officer granted formal permission for data collection from teachers and students working and serving in their respective schools. After getting the permission, the researcher himself and with the support of teachers, friends and relatives administer the questionnaire in the sample schools. The principals and the subject teachers of the concerned schools given full support to the researcher. The sampled principals, teachers and students showed their willingness in filling the questionnaires. 


\section{Data Analysis}

The collected data was analyzed and interpreted in the light of the objectives of the studies, through descriptive statistic in the form of percentage; means, standard deviation and simple regression analysis were used. Inferential Statistics was used in the form of Pearson's Product Moment Correlation ( $r$ ) since both the variable of the study were measured on interval scale which is considered as continuous scale (Lubke \& Muthen,2004; Glass et al, 1972). The Pearson Product Moment Correlation between leaderships' behaviour and teachers' performance was done through the following procedure:

- Leadership behaviour of each principal of each school was explored through teachers' questionnaire of the same school. Then the average response of teachers about their principal leadership behaviour was calculated.

- Teachers' performance of each school was investigated through their respective students of the same school. For this purpose, five TCPQs were distributed on each student to collect data about the performance of each teacher. Then the average performance of the teachers' responses was calculated for each school.

- After measuring the average leadership behaviour and teachers' performance of 67 schools, it was correlated through Pearson Product Moment Correlation through Statistical Package for Social Sciences (SPSS).

$\mathbf{H}_{\mathbf{0}}$ : $\quad$ There is no significant relationship between the principals' overall leadership behavior and teachers' performance in the classroom.

\section{Table 1}

Pearson's Product Moment Correlation (r) Between the Principals' Overall Leadership behaviour and Teachers' Performance

\begin{tabular}{lll}
\hline Variables & Pearson's Correlation $(r)$ & Remarks \\
\hline Principals' Leadership Behaviour & $0.7532^{*}$ & Strong \\
Teachers' Performance & & Positive \\
\hline
\end{tabular}

*Correlation is significant at 0.05

A Pearson's product-moment correlation was run to find out the relationship between principals' overall leadership behaviour and teachers' performance. The value of $r$ was found to be 0.7532 which clearly indicates a strong significant positive correlation between principals' leadership behaviour and teachers' performance. It indicates that better the principals' overall leadership behaviour the better will be the teachers' performance and so on. Hence, the null hypothesis, "There is no significant relationship between the principals' Overall leadership behavior and teachers' performance in the classroom" was rejected.

Ho2: $_{\text {or }}$ There is no significant relationship between the principals' leadership task oriented behavior and teachers' performance in the classroom. 
INTERNATIONAL JOURNAL OF ACADEMIC RESEARCH IN BUSINESS AND SOCIAL SCIENCES

Vol. 9, No. 1, Jan, 2019, E-ISSN: 2222-6990 (C) 2019 HRMARS

Table 2

Pearson's Product Moment Correlation (r) Between the Principals' Leadership Task Oriented Behavior and Teachers' Performance in the Classroom.

\begin{tabular}{lll}
\hline Variables & Pearson's Correlation $(r)$ & Remarks \\
\hline Leadership Task Oriented Behavior & $0.71213^{*}$ & Strong \\
Teachers' Performance & & Positive \\
\hline
\end{tabular}

*Correlation is significant at 0.05

A Pearson's product-moment correlation was run to determine the relationship between principals' leadership task oriented behavior and teachers' performance. The value of $r$ was found to be 0.71213 which plainly depicts a strong significant positive correlation between principals' leadership task oriented behavior and teachers' performance. It shows that better the principals' leadership task oriented behavior the better will be the teachers performance and so on. Hence, the null hypothesis, "There is no significant relationship between the principals' leadership task oriented behavior and teachers' performance in the classroom" was rejected.

Ho3: There is no significant relationship between the principals' leadership relationship oriented behavior and teachers' performance in the classroom.

\section{Table 3}

Pearson's Product Moment Correlation (r) Between the Principals' Leadership Relationship Oriented Behavior and Teachers' Performance

\begin{tabular}{llll}
\hline Variables & & Pearson's Correlation $(r)$ & Remarks \\
\hline Leadership Relationship & Oriented & & Strong \\
Behavior & & $0.7325^{*}$ & Positive \\
Teachers' Performance & & & \\
\hline
\end{tabular}

*Correlation is significant at 0.05

A Pearson's product-moment correlation was run to determine the relationship between principals' leadership behaviour and teachers' performance. The value of $r$ was found to be 0.7325 which clearly indicates a strong significant positive correlation between principals' leadership relationship oriented behavior and teachers' performance. It shows that better the principals' leadership relationship oriented behavior better will be the teachers performance and so on. Hence, the null hypothesis, "There is no significant relationship between the principals' leadership relationship oriented behavior and teachers' performance in the classroom" was rejected.

\section{Conclusion}

The main objective of the study was to investivage the principals' behaviour effects of teachers performance in classroom. This researched on the based on Pearson' product moment correlation, it proves that there is a strong positive correlation between principals' leadership behaviours and teachers' performance. Furthermore, it was found that there is strong positive 
correlation between the subscales of principals' leadership behaviour and teachers' performance. It means that better the principals' leadership behaviours better will be the teacher performance.

Glanz (2005) notes that excellence of a schools depends on the positive influence of its leadership behaviour. If the principal is incompetent the results will be in negative. According to (Kassim, Baharuddin, \& Khalib, 2018) leader should be involve employees in decision making and they should be sharing knowledge and welcoming to the employees. Hallinger, (1992) in his research examines interdependence of principal leadership behaviour and teachers' performance. Many researches have been conducted about the principals' leadership style and teachers' stress, job satisfaction and efficacy, turnout etc in many countries (Calik, et al. 2012; Walker \& Slear, 2011; Yilmaz 2007: Riffat-un-NisaAwan \& Bigger, 2008 Hoe ,2003) But no study has taken the data form all three sources (principal, teaches and the students) to actually know the effect of principals behavior leading to students outcomes at graduate level in Pakistan. This research contributes to the existing knowledge and also makes ways for the future researches in the same area. This study has significance for the Principals and teachers and students as they will know how can one be effected by the other.

\section{Recommendations}

1. The researcher recommends extending the exploration to include all levels of education. There might be unique contrasts in the levels of schools that make contrasts in the relationship amongst administrators and teachers and the effect of leadership behaviour. It is possible that rudimentary teachers are affected more by their principal's activities than middle school teachers. Secondary teachers might be less affected, or these groups might be similar to the group studies. Expanding the researcher over all levels of education could provide greater insight into the relationship of leadership behaviour and teachers' classrooms performance.

2. Expanding the researcher to include a qualitative aspect could contribute to better understanding concerning why instructors answered as they did. This information could lead to recommendations that might improve practice and give administrators more information as to what might improve the morale of their teachers. Additionally, teachers might suggest aspects of leadership behaviour that affect their performance that are not included in the questionnaire. At this type of research allowed teachers to express their opinions in detail would provide the data to expand this understanding.

3. Including a measure of student achievement in future research on teacher performance in the classroom and leadership behaviour would expand the current knowledge in the area. Student achievement is the key factor that is always the goal of improvement initiatives and projects. Including a measure to relate achievement to teacher morale and principal leadership behaviour would provide a direct link to the specific population studied with regard to the impact that performance and leadership behaviour had on achievement and would add to the body of knowledge in the area.

4. Uniform education management system should be established in the public and private sector schools. Which will bring sense of equality to the employees and they will not feel inferior or will not have low self-esteem as a result their performance will improve. 
INTERNATIONAL JOURNAL OF ACADEMIC RESEARCH IN BUSINESS AND SOCIAL SCIENCES

Vol. 9, No. 1, Jan, 2019, E-ISSN: 2222-6990 @ 2019 HRMARS

5. For the principals, training must be conducted before appointment as a manger/administrator in the institutions on relationship-oriented behavior.

6. In government secondary schools, conducive environment both for teaching and management cadre should be provided in the schools by the government. Both teaching and administrative faculty must have good coordination in the institutions.

\section{References}

Alimba, C. N. (2013). CONFLICT VARIABLES AS CORRELATES OF PUBLIC SECONDARY SCHOOL TEACHERS'PRODUCTIVITY IN ADAMAWA STATE, NIGERIA (Doctoral dissertation).

Bandara, W., Chand, D. R., Chircu, A. M., Hintringer, S., Karagiannis, D., Recker, J. C., ... \& Welke, R. J. (2010). Business process management education in academia: Status, challenges, and recommendations. Communications of the Association for Information Systems, 27, 743-776.

Barth, R. S. (2001). Teacher leader. Phi delta kappan, 82(6), 443-449.

Bass, B. M., \& Bass, R. (2009). The Bass handbook of leadership: Theory, research, and managerial applications. Simon and Schuster.

Bass, B. M., \& Riggio, R. E. (2006). Transformational leadership. Psychology Press.

Bhatti, K. K., \& Qureshi, T. M. (2007). Impact of employee participation on job satisfaction, employee commitment and employee productivity. International review of business research papers, 3(2), 54-68.

Bryk, A. S., Gomez, L. M., Grunow, A., \& LeMahieu, P. G. (2015). Learning to improve: How America's schools can get better at getting better. Harvard Education Press.

Burton, K. (2012). A study of motivation: How to get your employees moving. Management, 3(2), 232-234.

Calik, T., Sezgin, F., Kavagaci, H., \& Kilinc, A. (2012). Relationships between instructional leadership of school principals and self-efficacy of teachers and collective teacher efficacy. Educational Sciences: Theory \& Practice, 12(4), 2498-2504.

Child, J. (1972). Organizational structure, environment and performance: The role of strategic choice. sociology, 6(1), 1-22.

Chodkowski, M. (1999). Relationships between leader characteristics, planned change and organizational culture in a dynamic manufacturing environment.

COKER, O. M. (2012). Post-independence engagement paradigms in selected third-generation Nigerian Novels (Doctoral dissertation).

Cole, R. W. (2008). Educating everybody's children: Diverse teaching strategies for diverse learners. ASCD.

de Koster, R. B., Stam, D., \& Balk, B. M. (2011). Accidents happen: The influence of safety-specific transformational leadership, safety consciousness, and hazard reducing systems on warehouse accidents. Journal of Operations management, 29(7-8), 753-765.

De Witte, K., \& Marques, R. C. (2010). Designing performance incentives, an international benchmark study in the water sector. Central European Journal of Operations Research, 18(2), 189-220.

Dumas, C. M. (2010). Building leadership: The knowledge of principals in creating collaborative communities of professional learning. 
INTERNATIONAL JOURNAL OF ACADEMIC RESEARCH IN BUSINESS AND SOCIAL SCIENCES

Vol. 9, No. 1, Jan, 2019, E-ISSN: 2222-6990 @ 2019 HRMARS

Evans, L. (1997). Understanding teacher morale and performance .Teaching and Teacher Education, 13, 831-845. Retrieved November 3, 2007, from PsycINFO database.

Fenwick, T., \& Edwards, R. (2010). Actor-network theory in education. Routledge.

Glanz, J. (2005). What every principal should know about instructional leadership. Corwin Press.

Hallinger, P. (1992). The evolving role of American principals: From managerial to instructional to transformational leaders. Journal of Educational Administration, 30(3).

Hanaysha, J. (2016). Examining the effects of employee empowerment, teamwork, and employee training on organizational commitment. Procedia-Social and Behavioral Sciences, 229, 298-306.

Hansen, D. T. (2017). The teacher and the world: A study of cosmopolitanism as education. Routledge.

Hui, H., Jenatabadi, H. S., Ismail, B., Azina, N., Radzi, W. M., \& Jasimah, C. W. (2013). Principal's leadership style and teacher job satisfaction: A case study in China.

Humphreys, J. H., \& Einstein, W. O. (2004). Leadership and temperament congruence: Extending the expectancy model of work motivation. Journal of Leadership \& Organizational Studies, 10(4), 58-79.

Hunter-Boykin, H. S., Evans, V. (1995). The relationship between high school principals' leadership and teachers' morale. Journal of Instructional Psychology, 22(2). 152- 162.

Jung, D. I., Chow, C., \& Wu, A. (2003). The role of transformational leadership in enhancing organizational innovation: Hypotheses and some preliminary findings. The leadership quarterly, 14(4-5), 525-544.

Kassim, N. A., Baharuddin, K., \& Khalib, L. H. (2018). Organizational Culture and Leadership as Factors of Organizational Learning Capabilities. International Journal of Academic Research in Progressive Education and Development, 7(3), 268-277.

Kasser, T., Davey, J., \& Ryan, R. M. (1992). Motivation and employee-supervisor discrepancies in a psychiatric vocational rehabilitation setting. Rehabilitation Psychology, 37(3), 175.

Kunze, F., Boehm, S. A., \& Bruch, H. (2011). Age diversity, age discrimination climate and performance consequences-a cross organizational study. Journal of organizational behavior, 32(2), 264290.

Lee, Y. J. \& Wilkins, V. M. (2011). More similarities or more differences? Comparing public and nonprofit managers' job motivations. Public Administration Review, 71(1), 45-56.

Leonard, A. (2010). The story of stuff: How our obsession with stuff is trashing the planet, our communities, and our health-and a vision for change. Simon and Schuster.

Miner, A. S., Bassof, P., \& Moorman, C. (2001). Organizational improvisation and learning: A field study. Administrative science quarterly, 46(2), 304-337.

Morrison, E. W., \& Robinson, S. L. (1997). When employees feel betrayed: A model of how psychological contract violation develops. Academy of management Review, 22(1), 226-256.

Pfeffer, J. (2005). Producing sustainable competitive advantage through the effective management of people. Academy of Management Perspectives, 19(4), 95-106.

Ridzuan, A. R. Bin, Baharudin, N. 'Aqilah binti A., Ismail, S., Arham, A. F., Nazri, N. M., \& Rahman, M. F. A. (2018). Measuring the Factors of Employees' Job Satisfaction among Lecturers in UiTM Melaka. International Journal of Academic Research in Business and Social Sciences, 8(10), 899914 
INTERNATIONAL JOURNAL OF ACADEMIC RESEARCH IN BUSINESS AND SOCIAL SCIENCES

Vol. 9, No. 1, Jan, 2019, E-ISSN: 2222-6990 C 2019 HRMARS

Riffat-un-NisaAwan \& Bigger,S. (2008). Monitoring the quality of secondary education in the context of decentralization in Pakistan. Bulletin of education research: Institute of Education \&Research.

Simanjuntak, H., Pandjaitan, N. K., \& Kuswanto, S. (2018). Effect of Style of Leadership on Implementation of Organizational Culture, Motivation and Performance of PT HNR TBK Employees. International Journal of Academic Research in Business and Social Sciences, 8(12), $98-108$.

Sparks, K., Faragher, B., \& Cooper, C. L. (2001). Well-being and occupational health in the 21st century workplace. Journal of occupational and organizational psychology, 74(4), 489-509.

Suebwongpat, I. (2014). The Role of HRM System and Organisational Culture in Employee Engagement and Organisational Performance.

Tsui, A. S., Pearce, J. L., Porter, L. W., \& Tripoli, A. M. (1997). Alternative approaches to the employeeorganization relationship: does investment in employees pay off?. Academy of Management journal, 40(5), 1089-1121.

Walker, J., \& Slear, S. (2011). The impact of principal leadership behaviors on the efficacy of new and experienced middle school teachers. NASSP Bulletin, 95(1), 46-64.

Yilmaz, S. (2007). "The relationship between organizational trust and organizational Commitment in Turkish primary schools". World Applied Sciences Journal 3 (5), 775-78 